\title{
Premarital hepatitis screening
}

\author{
Attitude towards screening and the risk factors for transmission
}

Ibtehaj M. Alharbi, MBBS, Badr M. Aljarallah, ABIM, FACP.

\begin{abstract}

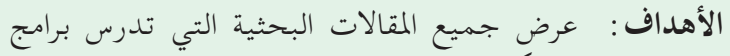

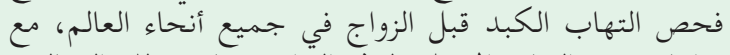

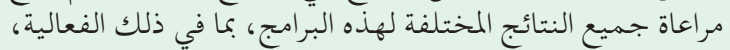

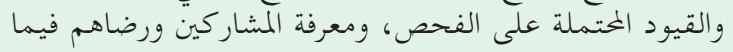
يتعلق بالبرنامج · و الميولة
\end{abstract}

الطرِيقة: استخدمت المراجعة المنهجية الحالية قواعد بيانات كلاً من Google Scholar و Ovid Medline و PubMed للبحث عن المقالات المتعلقة بكل من وند و

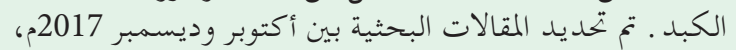

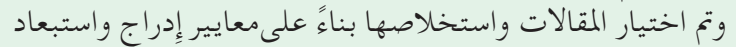

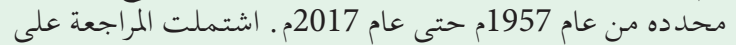

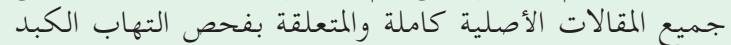

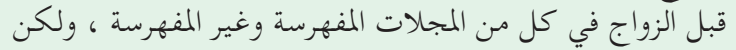

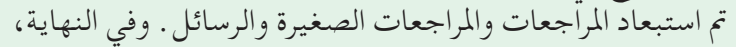

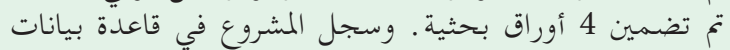
PROSPERO

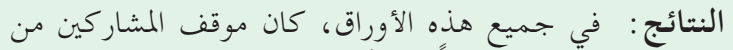

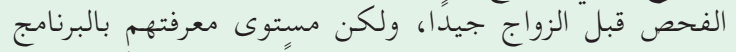

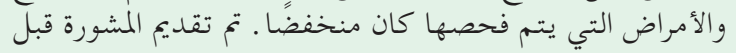

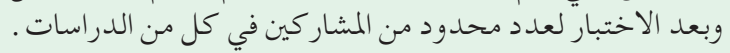

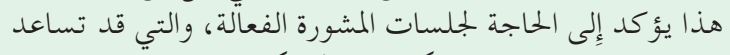

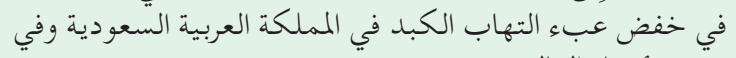

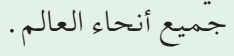

الحخاتمة: أن دور الطبيب الممارس في أي برنامج فحص هو تقديم

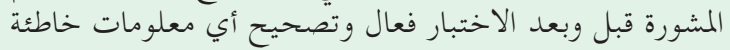

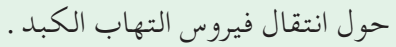

Objective: To explore all research articles investigating hepatitis premarital screening programs (PSPs) worldwide, considering all different outcomes of such programs, including efficacy, possible limitations to screening, and participants' knowledge and satisfaction regarding the program.
Methods: The present systematic review used the databases of PubMed, Ovid Medline, and Google Scholar to search for articles related to both PSPs and the hepatitis viruses. Research articles were identified between October and December 2017, and articles were selected and extracted based on predefined inclusion and exclusion criteria from the year 1957 up to 2017. The review included all full-length original articles related to premarital hepatitis screening in both indexed and non-indexed journals, but reviews, mini-reviews, and letters were excluded. Ultimately, 4 research papers were included. While conducting the search, the project was registered on PROSPERO database.

Results: In all these papers, the participants' attitude toward premarital screening was good, but their level of knowledge about the program and the diseases being screened was low. Pre- and post-test counseling were provided to only a limited number of participants in each of the studies. This emphasizes the need for effective counseling sessions, which may help in decreasing the hepatitis burden in Saudi Arabia and worldwide.

Conclusions: The role of the practicing physician in any screening program is to provide effective pre and post-test counseling and correct any misinformation about the transmission of the hepatitis viruses.

PROSPERO Registration number: CRD42018096535

Saudi Med J 2018; Vol. 39 (12): 1179-1185 doi: 10.15537/smj.2018.12.23495

From the College of Medicine (Alharbi), Qassim University, Division of Gastroenterology and Hepatology (Aljarallah), Qassim University Medical City, Qassim, Kingdom of Saudi Arabia.

Address correspondence and reprint request to: Dr. Badr $M$. Aljarallah, Division of Gastroenterology and Hepatology, Qassim University Medical City, Qassim, Kingdom of Saudi Arabia. E-mail:bmj@qumed.edu.sa

ORCID ID: orcid.org/0000-0003-2169-9925 
$\mathrm{I}^{\mathrm{n}}$ n 1935, the United States passed a law requiring premarital syphilis testing in all citizens wishing to be married. Since then, many countries have developed their own specific medical tests before issuing marriage certificates. ${ }^{1}$ Meanwhile, the benefits, costs, and even ethical consequences of such programs have been much debated. In Saudi Arabia, the premarital screening program (PSP) was introduced to investigate and reduce the risk of transmitting contagious infections to partners or children. In addition, the program tests for genetic carriers of hereditary blood diseases such as thalassemia and sickle cell anemia. Indeed, genetic screening for carriers of the hemoglobin A2 and hemoglobin $S$ is of more value in the Arab world where there is a high rate of consanguinity. ${ }^{2}$ Recently, screening for the hepatitis viruses was also introduced into the PSP in Saudi Arabia. The World Health Organization (WHO) estimates that the prevalence rates of hepatitis $\mathrm{B}$ and $\mathrm{C}$ around the world are 257 million and 71 million, respectively. In 2015 , approximately 1.2 million deaths were caused by complications from these infections, mostly cirrhosis and hepatocellular carcinoma. Specifically, cirrhosis will develop in $10-20 \%$ of patients chronically infected with hepatitis $\mathrm{B}^{3}$ and in $15-30 \%$ of those with hepatitis $\mathrm{C}^{4}$

A large number of patients seropositive for hepatitis $\mathrm{B}$ live in the developing world, while hepatitis $\mathrm{C}$ is more unevenly distributed with a higher prevalence in the European and Eastern Mediterranean regions. ${ }^{5}$ The hepatitis $B$ and $\mathrm{C}$ viruses (HBV and $\mathrm{HBC}$ ) can both be spread through blood transfusion, needles, or vertically during birth. However, the transmission rate of each virus is different, and $\mathrm{HBV}$ can be transmitted through sexual contact, while with $\mathrm{HCV}$, it is very unlikely to happen. Furthermore, in the case of HCV, the horizontal route is the main mode of transmission, which is why many individuals infected with this virus were either intravenous drug users or patients on hemodialysis. ${ }^{6}$ It is estimated that 257 million people worldwide are infected with hepatitis $B$, and the prevalence is highest in the Western Pacific and African Region. ${ }^{3}$ Many strategies have been developed to eradicate the hepatitis B epidemic, the most important being a mass vaccination program in infants. Other approaches to combatting hepatitis B and C include blood screening, national health screening, and improvements in socioeconomic and sanitary conditions. Most countries

Disclosure. Authors have no conflict of interests, and the work was not supported or funded by any drug company. mandate premarital screening for thalassemia and sickle cell anemia with sexually transmitted disease (STD) testing being voluntary. ${ }^{7}$ Others, such as Saudi Arabia, and previously China and the United States, have compulsory premarital screening for the human immunodeficiency virus (HIV) and HBV. However, the only country that currently mandates premarital testing for HCV is Saudi Arabia. ${ }^{7}$ Premarital screening often involves 1) taking a medical history with a special emphasis on family history of hereditable diseases and 2) performing a physical examination, which may include a pelvic examination in women and an examination of secondary sexual characteristics in men. However, laboratory investigation constitutes the main objective assessment in premarital screening, whereby a blood sample is taken and tested for complete blood count, hematological markers, and virological markers of HIV, $\mathrm{HBV}$, and HCV. ${ }^{8,9}$ In Saudi Arabia, premarital screening was introduced in February 2004. The program was preceded by a media campaign to educate the general public on its importance in preventing transmission of hereditary diseases to offspring. ${ }^{10}$ The Saudi PSP first included sickle cell anemia and beta-thalassemia. However, tests for HIV, HBV, and HCV were added to the program 4 years later. ${ }^{7}$

Because few studies have addressed this topic and because premarital screening for hepatitis is only performed in certain countries, it is necessary to summarize all existing data. Thus, the present systematic review aimed to explore all research articles investigating hepatitis PSPs worldwide, considering all different outcomes of such programs, including efficacy, possible limitations to screening, and participants' knowledge and satisfaction regarding the program. A comprehensive summary of the existing research is needed so that clinicians can educate patients with hepatitis and their partners, as well as correct any misinformation about the hepatitis viruses.

Methods. All the research articles investigating the hepatitis premarital screening program worldwide were considered. We included all full-length original articles discussing hepatitis PSPs and considering all different outcomes of such programs in both indexed and non-indexed journals. There were no specific inclusion criteria regarding study design, but reviews, mini-reviews, letters, and gray literature were excluded. We also excluded studies that were unrelated to the subject; those involving premarital screening for other diseases or hepatitis screening programs that were not premarital. Experimental studies were also excluded, as were Knowledge, Attitudes, and Practices (KAP) 
studies that were performed before the implementation of premarital hepatitis screening in their respective countries. Finally, research articles that were only published as an abstract, as part of a conference proceedings, or in any language other than English were also excluded (Figure 1).

Relevant studies published between 1957 and December 31, 2017 were identified between October and December 2017 using the databases of PubMed, Ovid Medline, and Google Scholar. We used the following key terms in the search: "premarital examinations," "premarital screening," "premarital hepatitis screening," with each also combined with the terms "hepatitis B virus," "hepacivirus," "hepatitis C virus," "HBV," and "HCV."

Overall, 24 articles were identified as relevant based on the search conditions above, and the data were extracted by 2 authors (I.M. and B.A.), who independently performed the search and resolved any discrepancy by consensus. Neither of these authors were blinded to the author names and affiliations, methods, or results of the previous studies. Nine of the studies were excluded based on the abstract alone, while the full texts of the other 15 were read and screened by both authors. Ten more were subsequently excluded because they were irrelevant to the current research question. Specifically, 5 studies addressed the prevalence and management of hepatitis antigen positivity in a specific population, ${ }^{11-15} 2$ measured incidence trends or population perception of hepatitis $\mathrm{B}$ and $\mathrm{C}$ before any hepatitis PSP had been established, , ${ }^{16,17} 2$ targeted diseases other than hepatitis, ${ }^{18,19}$ and one assessed physicians' attitudes toward general HCV screening. ${ }^{20}$ One further study was excluded because it mainly discussed risk factors for transmission in the community and not screening for the viruses. ${ }^{21}$ Ultimately, 4 articles were selected. ${ }^{8,22-24}$ These were then reviewed for quality by a senior gastroenterologist (B.A.).

After screening the 4 articles mentioned previously, the authors have concluded that the main findings were: 1) the knowledge-attitude of the general population toward hepatitis screening and 2) the risk factors for the spread of these viruses in the Saudi population.

The process of data extraction and selection conformed to the Preferred Reporting Items for Systematic Reviews and Meta-Analyses (PRISMA) statement for systematic review of observational studies, and while conducting the search, the project was registered on PROSPERO database.

Finally, the possibility for a meta-analysis was assessed. However, further analysis was not possible because outcomes measured were not homogeneous across the studies.

Results. Three of the 4 included articles were cross-sectional studies, while the other included 2 objectives that resulted in a study with both a cross-sectional (Paper \#1) and a case-control design (Paper \#2). ${ }^{22}$ Therefore, we considered the number of studies as 5 instead of 4 (Table 1). Three out of the 4

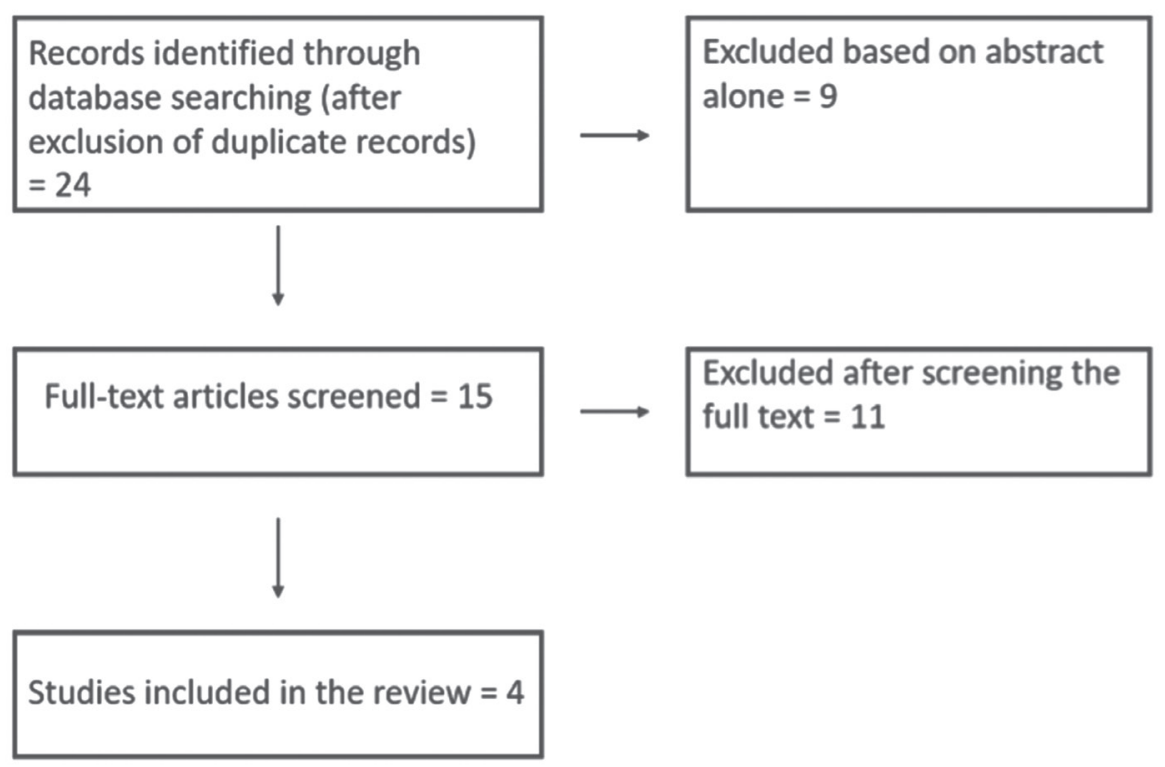

Figure 1 - Flow diagram of the study. 
cross-sectional studies investigated the knowledge and attitudes of the general population toward premarital hepatitis screening, $, 82,24$ while one measured the prevalence of the hepatitis viruses among attendants at premarital screening clinics. $^{22}$ The remaining investigation was a case-control study to identify risk factors for the spread of these infections. ${ }^{22}$ The search strategy applied in this review was not restricted to studies originating from Saudi Arabia, and it included studies from all countries worldwide. However, only one research paper from outside Saudi Arabia (Iran) met the inclusion criteria. The studies included in the present review consisted of different populations: the attendants of premarital screening clinics and general outpatient clinics (well-baby, hematology, and genetics) and female university students.

Table 1 - Details of studies included in the present systematic review.

\begin{tabular}{|c|c|c|c|c|c|c|}
\hline References & Subjects & Method & $\begin{array}{l}\mathrm{N} \text { of } \\
\text { patients }\end{array}$ & Objective & Results & Limitations \\
\hline $\begin{array}{l}\text { Alswaidi \& } \\
\text { O’Brien, } \\
2010^{22} \\
\text { (Paper \#1) }\end{array}$ & $\begin{array}{l}\text { Ministry of } \\
\text { Health database }\end{array}$ & $\begin{array}{l}\text { Cross-sectional } \\
\text { descriptive } \\
\text { study }\end{array}$ & 74,662 & $\begin{array}{l}\text { To ascertain the } \\
\text { prevalence of HBV and } \\
\mathrm{HCV} \text { and thus produce } \\
\text { evidence to informed } \\
\text { decision-making based } \\
\text { on the inclusion of } \\
\text { these infections in the } \\
\text { screening program. }\end{array}$ & $\begin{array}{l}\text { The average prevalence was } \\
1.31 \% \text { for } \mathrm{HBV} \text { and } 0.33 \% \\
\text { for } \mathrm{HCV} \text {. }\end{array}$ & $\begin{array}{l}\text { The study included } \\
\text { only younger } \\
\text { participants } \\
\text { subjected to } \\
\text { premarital screening. }\end{array}$ \\
\hline $\begin{array}{l}\text { Alswaidi \& } \\
\text { O’Brien, } \\
2010^{22} \\
\text { (Paper \#2) }\end{array}$ & $\begin{array}{l}\text { Attendants of } \\
\text { a premarital } \\
\text { screening } \\
\text { program } \\
\text { (participants who } \\
\text { were positive } \\
\text { for HBV, HCV, } \\
\text { or HIV were } \\
\text { defined as cases) }\end{array}$ & $\begin{array}{l}\text { Case-control } \\
\text { study }\end{array}$ & 540 & $\begin{array}{l}\text { To ascertain the risk } \\
\text { factors responsible for } \\
\text { infection transmission } \\
\text { and thus produce } \\
\text { evidence to informed } \\
\text { decision-making based } \\
\text { on the inclusion of } \\
\text { these infections in the } \\
\text { screening program. }\end{array}$ & $\begin{array}{l}\text { Sharing of personal belongings } \\
\text { (particularly razors), } \\
\text { blood transfusions, cuts at } \\
\text { barbershops, and extramarital } \\
\text { sexual relationships showed the } \\
\text { highest significant associations } \\
\text { with virus transmission. }\end{array}$ & $\begin{array}{l}\text { Risk factors were not } \\
\text { virus-specific. }\end{array}$ \\
\hline $\begin{array}{l}\text { Adibi et al, } \\
2010^{23}\end{array}$ & $\begin{array}{l}\text { Attendants } \\
\text { of premarital } \\
\text { screening } \\
\text { program }\end{array}$ & $\begin{array}{l}\text { Cross-sectional, } \\
\text { questionnaire- } \\
\text { based study }\end{array}$ & 1,316 & $\begin{array}{l}\text { To evaluate the } \\
\text { attitudes of the young } \\
\text { adult population toward } \\
\text { premarital screening for } \\
\text { the hepatitis B virus. }\end{array}$ & $\begin{array}{l}73.2 \% \text { of participants approved } \\
\text { of HBV screening. Male } \\
\text { gender and higher education } \\
\text { level were associated with } \\
\text { positive attitudes. }\end{array}$ & $\begin{array}{l}\text { The research related } \\
\text { only to the hepatitis } \\
\text { B virus. }\end{array}$ \\
\hline $\begin{array}{l}\text { Ibrahim et } \\
\text { al, } 2011^{24}\end{array}$ & $\begin{array}{l}\text { Unmarried } \\
\text { female students } \\
\text { at King } \\
\text { Abdulaziz } \\
\text { University, } \\
\text { Jeddah, Saudi } \\
\text { Arabia }\end{array}$ & $\begin{array}{l}\text { Cross-sectional, } \\
\text { questionnaire- } \\
\text { based study }\end{array}$ & 1,549 & $\begin{array}{l}\text { To assess the knowledge } \\
\text { and attitudes of } \\
\text { unmarried female } \\
\text { students toward } \\
\text { premarital screening } \\
\text { and to determine } \\
\text { predictors of high } \\
\text { student knowledge } \\
\text { scores. }\end{array}$ & $\begin{array}{l}\text { The students' knowledge about } \\
\text { the program was generally } \\
\text { low before the educational } \\
\text { campaign. The predictors } \\
\text { of high knowledge scores } \\
\text { were enrollment in a health } \\
\text { science study program, age } \\
\geq 20 \text { years, family history of } \\
\text { hereditary diseases, and income } \\
\geq 10,000 \text { SAR/month. After } \\
\text { the educational program, the } \\
\text { students' knowledge about } \\
\text { premarital screening was } \\
\text { markedly improved. }\end{array}$ & $\begin{array}{l}\text { Time was limited } \\
\text { between the } \\
\text { educational } \\
\text { intervention and the } \\
\text { conduction of the } \\
\text { post-test survey. }\end{array}$ \\
\hline $\begin{array}{l}\text { Ibrahim et } \\
\text { al, } 2011^{8}\end{array}$ & $\begin{array}{l}\text { Attendants of } \\
\text { outpatient clinics } \\
\text { at } 3 \text { hospitals in } \\
\text { Jeddah, Saudi } \\
\text { Arabia }\end{array}$ & $\begin{array}{l}\text { Cross-sectional } \\
\text { questionnaire- } \\
\text { based study }\end{array}$ & 655 & $\begin{array}{l}\text { To assess the knowledge } \\
\text { and attitudes of } \\
\text { individuals attending } \\
\text { outpatient clinics } \\
\text { regarding premarital } \\
\text { screening and to } \\
\text { determine satisfaction } \\
\text { and recommendations } \\
\text { of clients of the } \\
\text { program }\end{array}$ & $\begin{array}{l}\text { The participants' knowledge } \\
\text { about the program was } \\
\text { generally low. Regarding } \\
\text { attitudes, the vast majority of } \\
\text { participants }(96 \%) \text { strongly } \\
\text { agreed on the importance of } \\
\text { the program, and } 80 \% \text { gave } \\
\text { an excellent or very good score } \\
\text { for program confidentiality, } \\
\text { whereas lower scores were given } \\
\text { for counseling. }\end{array}$ & $\begin{array}{l}\text { This was conducted } \\
\text { in only one city in } \\
\text { Saudi Arabia. }\end{array}$ \\
\hline
\end{tabular}


Knowledge and attitudes. All survey-based studies $8,23,24$ agreed that the attitude toward premarital screening was relatively high with most participants agreeing on the importance of such programs. For example, in both Ibrahim et $\mathrm{al}^{8,24}$ studies; university college students $(92.8 \%)$ and the attendants of premarital screening clinics $(83.2 \%)$ had strongly agreed on the importance of PSP, $73.2 \%$ of participants included in Adibi et $\mathrm{al}^{23}$ study were willing to be screened for hepatitis B. However, the respondents had little knowledge of the program, the diseases being screened, or the investigations being performed.

The same studies also investigated factors that predicted a more positive attitude toward screening. For instance, in the first Ibrahim et $\mathrm{al}^{24}$ study, unmarried university students were offered a questionnaire to be completed before (pre-test) and immediately after (post-test) an educational presentation that discussed all the items covered in the questionnaire. The student knowledge about the program before the presentation was unsatisfactory; $80.9 \%$ had poor knowledge scores before the presentation, and only $6.6 \%$ of them had satisfactory scores. However, the mean scores had improved in all knowledge aspects; $1.42 \pm 1.25$ to $3.76 \pm 1.30$ in knowledge regarding the PSP program, $5.76 \pm 3.34$ to $8.99 \pm 2.87$ in the investigation being carried out, and $2.06 \pm 1.9$ to $3.96 \pm 1.94$ in the diseases being screened, which included only questions about hemoglobinopathy. In general, the total knowledge scores had changed from 9.85 \pm 5.36 pre-test to $18.45 \pm 4.96$, both of which were statistically significant $(p<0.0001)$. The most important factors contributing to a high knowledge score were enrollment in a health science college, age $\geq 20$ years, family history of a genetic disease, and high family income.

In the second, data were collected at the outpatient clinics of 3 hospitals in Jeddah. ${ }^{8}$ In this study, $80.5 \%$ had poor knowledge score and only $5.5 \%$ had satisfactory scores. The most notable demographic characteristics associated with a better attitude toward PSPs were Saudi nationality, age $<30$ years, high education or income, and previous experience with the PSP. In the first paper mentioned above, after the educational presentation and following a 20-minute discussion, a post-test questionnaire was given in which knowledge scores were significantly improved. The students and outpatient clinic attendants in the 2 studies both reported that family and friends were their common source of knowledge about the PSP. The Iranian paper by Adibi et $\mathrm{al}^{23}$ was similar to the Ibrahim et $\mathrm{a}^{24}$ study from Jeddah, except that only the attendants of premarital screening clinics were included. The results showed that $73 \%$ of the participants approved the HBV testing, and that approximately one third would still get married if the test result was positive. Unlike the second Ibrahim et al study, the Adibi investigation showed that men had a better attitude toward HBV screening. Furthermore, women were significantly more likely than men to change their choice of marriage partner if the tests results were positive as well as to be depressed after a positive result.

Among all the included papers, only the second study noted above surveyed participants who had visited a premarital screening clinic about their experience, satisfaction, and any recommendations to improve the program. The study found that the most common measure taken during the visit was laboratory investigation. Approximately one-third of participants reported that the physician had taken a history or performed a physical examination. Surprisingly, counseling before the tests was provided to only $11.7 \%$ of respondents, and was found to be the area of least satisfaction. ${ }^{8}$ This finding corroborates the first study by Alswaidi and O'Brien, ${ }^{22}$ which obtained similar results regarding counseling. Only half of the participants who were positive for HBV, HCV, and HIV were educated by the program staff. In addition, of the 224 individuals found to be positive for one of these viruses, 208 $(92.8 \%)$ continued or intended to continue with the marriage.

Risk factors for transmission. Hepatitis B, HCV, and HIV share similar modes of infection, although the likelihood of infection via each mode differs among the virus types. The fourth paper in the present review was a case-control study by Alswaidi and O'Brien, ${ }^{22}$ which did not report virus-specific risk factors for modes of infection transmission. Nevertheless, it did highlight the most important risk factors contributing to the transmission of all of theseviruses in the Saudi population. These factors, in descending order, were razor sharing $(\mathrm{OR}=16.95)$, blood transfusion $(\mathrm{OR}=15.50)$, accidental needle injuries $(\mathrm{OR}=10.25)$, close contact with an infected person $(\mathrm{OR}=9.48)$, receiving multiple cuts in barbershops $(\mathrm{OR}=6.10)$, multiple acne puncturing $(\mathrm{OR}=5.42)$, being married $(\mathrm{OR}=4.69)$, chronic illness $(\mathrm{OR}=3.83)$, being divorced or widowed $(\mathrm{OR}=3.76)$, extramarital sexual relationships $(\mathrm{OR}=3.29)$, and dental work or oral surgery $(\mathrm{OR}=1.60)$.

Discussion. This review explored all research articles investigating hepatitis PSPs worldwide and emphasized the need for an educational program to improve knowledge regarding PSPs in all age groups. This review is the first to be conducted after the implementation 
of hepatitis PSPs in Saudi Arabia, and hepatitis C premarital screening worldwide. Nevertheless, one of the limitations was the deficiency found in medical literature regarding this topic, and the heterogenicity found in published literature concerning hepatitis PSPs.

Premarital hepatitis screening in Saudi Arabia was started in January 2008 along with HIV testing. ${ }^{8}$ The first large-scale study to investigate the prevalence of $\mathrm{HBV}$ and HCV in the Saudi population was the first study by Alswaidi et $\mathrm{al},{ }^{25}$ which was carried out in 2008. However, the results of the study, which involved the attendants of premarital screening clinics, were limited and mostly represented the younger population subjected to premarital screening. Other studies including older age groups found a higher prevalence of hepatitis B (3.8\%) and C $(0.41 \%)$.

Clinical experience of stigma attached to hepatitis $B$ diagnosis. Stigma is defined as "the situation of the individual who is disqualified from full social acceptance," ${ }^{26}$ and health-related stigma is a barrier that hinders the accessibility of health care services to those in need. Unlike HCV, HBV-related stigma has not been fully studied, especially in Saudi Arabia.

A positive $\mathrm{HBV}$ result has many implications beyond health-related issues for the individual, particularly social and financial effects. The Adibi et $\mathrm{al}^{23}$ study showed this well, where a large proportion (more than $40 \%$ ) of respondents claimed that they might feel greatly depressed if their HBV result was positive. The stigmatization of a disease serves as a limitation to seeking diagnosis and commencing treatment. Furthermore, the fear of loss of confidentiality can cause further worry and apprehension. Most research conducted on this subject has found an inverse relationship between the participants' knowledge level and their stigma scores. Moreover, a high stigma score was the only factor that significantly decreased the likelihood of previous screening for HBV. The stigmatizing attitude found in these studies was highest when the statement was related to the concept of contagion. ${ }^{27-29}$

Misinformation about the transmission of hepatitis viruses has contributed to social isolation and low self-esteem in patients. ${ }^{29}$ To solve this problem, we recommend that physicians should be educated about hepatitis B so that they can provide proper counseling during hepatitis screening programs. This would improve participants' and physicians' knowledge of HBV in the community and hence, reduce stigmatization.

Counseling. It seems that the most effective method of educating prospective marriage partners was pre-test and post-test counseling. Counseling should start before a medical history is taken; partners should be educated about the goals of the PSP, what to expect, how the results are interpreted, how to deal with positive results, and, most importantly, the possibility of a false positive. ${ }^{30}$ In the second Ibrahim et al study, counseling was the area of least satisfaction among the participants. Pre-test counseling was given to only $11.7 \%$ of the 655 participants interviewed, and it was directed mainly toward the benefits of screening and the susceptibility of transmission. ${ }^{8}$ In a 2010 study that focused on postmarital follow-up counseling to high-risk carriers of thalassemia and sickle cell anemia, $31 \%$ of participants reported that insufficient time was spent discussing the results, with the majority receiving their results from paramedical personnel (nurses, medical technologist, and laboratory clerks) rather than from physicians. ${ }^{31}$ No studies have fully investigated HBV and HCV virus counseling in Saudi Arabia. Nevertheless, the results of these survey studies are not encouraging. In the second Ibrahim et al study, 90\% of participants recommended adding more counseling to the program. Furthermore, in the second Alswaidi and O'Brien study, which was performed in 2008, half of the patients infected with $\mathrm{HBV}, \mathrm{HCV}$, or HIV received no health education about their disease, and $77 \%$ continued with the marriage. ${ }^{22}$ Some studies have even suggested that screening before university admission may be more effective than screening after a marriage proposal has already been made. ${ }^{32}$ This can result in more awareness about the disease at an earlier time point so that suitable measures can be sought before marriage.

Therefore, comprehensive counseling must be the main end goal of any screening program. Indeed, a positive result in a patient without any education may not have a significant impact on disease incidence. Instead, education about what to expect from the PSP is necessary for primary prevention of diseases being screened.

In conclusion, the survey-based studies have demonstrated that the participants' attitude toward premarital screening was high, but their knowledge about the program and the diseases being screened was low. Pre- and post-test counseling were provided to only a limited number of participants in each of the studies.

This review article emphasizes the need for an educational program to improve knowledge regarding PSPs. Moreover, effective counseling sessions should be provided to every partner before and after testing. Pre-marital counseling is an essential part of the effort to decrease the hepatitis burden in Saudi Arabia. This study can be useful for lawmakers to include more screenings throughout the country and to physicians 
who need to be aware of how to approach these patients in their daily practice. Finally, this study can also be useful for non-governmental organizations promoting health awareness among primary health care workers and nurses. Future research must investigate the specific risk factors for the transmission of each of these hepatitis viruses in the Saudi population. This may help in the design of preventive measures against the further spread of these viruses.

Acknowledgment. We would like to thank Scribendi (www. scribendi.com) for English language editing.

\section{References}

1. Kingon RJ, Wiesner PJ. Premarital syphilis screening: Weighing the benefits. Am J Public Health 1981; 71: 160-162.

2. Alhamdan NA, Almazrou YY, Alswaidi FM, Choudhry AJ. Premarital screening for thalassemia and sickle cell disease in Saudi Arabia. Genet Med 2007; 9: 372-377.

3. World Health Organization. Hepatitis B. [cited 2017 August 3]. Available from: http://www.who.int/mediacentre/factsheets/ fs204/en/

4. World Health Organization. Hepatitis C. [cited 2017 August 3]. Available from: http://www.who.int/mediacentre/factsheets/ fs $164 /$ en/

5. World Health Organization. Global hepatitis report, 2017. [cited 2017 August 3]. Available from: http://www.who.int/ hepatitis/publications/global-hepatitis-report2017/en/

6. Clarke A, Kulasegaram R. Hepatitis C transmission - Where are we now? Int J STD AIDS 2006; 17: 74-80.

7. Alswaidi FM, O’Brien SJ. Premarital screening programmes for haemoglobinopathies, HIV and hepatitis viruses: Review and factors affecting their success. J Med Screen 2009; 16: 22-28.

8. Ibrahim NK, Bashawri J, Al Bar H, Al Ahmadi J, Al Bar A, Qadi $M$, et al. Premarital screening and genetic counseling program: Knowledge, attitude, and satisfaction of attendees of governmental outpatient clinics in Jeddah. J Infect Public Health 2013; 6: 41-54.

9. Hesketh T. Getting married in China: pass the medical first. BMJ 2003; 326: 277-279.

10. El-Hazmi MAF. The natural history and the national pre-marital screening program in Saudi Arabia. Saudi Med J 2004; 25: 1549-1554.

11. Ziegler FD, Miller J, Kelly J. Hepatitis-associated antigen and antibody in drug addicts and premarital sera. Lancet 1971; 2: 1034.

12. Akahane Y, Kojima M, Sugai Y, Sakamoto M, Miyazaki Y, Tanaka T, et al. Hepatitis $C$ virus infection in spouses of patients with type C chronic liver disease. Ann Intern Med 1994; 120: 748-752.

13. Flichman DM, Blejer JL, Livellara BI, Re VE, Bartoli S, Bustos JA, et al. Prevalence and trends of markers of hepatitis B virus, hepatitis $C$ virus and human Immunodeficiency virus in Argentine blood donors. BMC Infect Dis 2014; 14: 218.

14. Eisa ZM, Eifan SA, Al-Sum BA. Prevalence of HBV, HCV, and HIV infections among individuals included in premarital screening program at Jazan Province, Saudi Arabia. Indian J Public Heal Res Dev 2012; 3: 23-26.
15. Tosun S, Yücetürk M, Dönmez AB, Gündüz T. Rapid immunization scheme for spouses of individuals estabilished as hepatitis B carriers during premarital tests. Clin Dev Immunol 2012; 2012: 10-13.

16. Memish ZA, Knawy BA, El-Saed A. Incidence trends of viral hepatitis A, B, and C seropositivity over eight years of surveillance in Saudi Arabia. Int J Infect Dis 2010; 14: e115-e120.

17. Alam AA. Perception of female students of king saud university towards premarital screening. J Family Community Med 2006; 13: 83-88.

18. Al-Arrayed SS, Hafadh N, Al-Serafi S. Premarital counselling: an experience from Bahrain. Eastern Mediterranean Health Journal 1997; 3: 415-419.

19. Al Sulaiman A, Saeedi M, Al Suliman A, Owaidah T. Postmarital follow-up survey on high risk patients subjected to premarital screening program in Saudi Arabia. Prenat Diagn 2010; 30: 478-481.

20. Massari V, Retel O, Flahault A. How do general practitioners approach hepatitis $\mathrm{C}$ virus screening in France? Eur J Epidemiol 1999; 15: 119-124.

21. Jimenez AP, El-Din NS, El-Hoseiny M, El-Daly M, Abdel-Hamid M, El Aidi S, et al. Community transmission of hepatitis B virus in Egypt: results from a case-control study in Greater Cairo. Int J Epidemiol 2009; 38: 757-765.

22. Alswaidi FM, O’Brien SS. Is there a need to include HIV, HBV and HCV viruses in the Saudi Premarital Screening Programme on the basis of their prevalence and transmission risk factors? J Epidemiol Community Heal 2010; 64: 989-997.

23. Adibi P, Zavareh J, Mohseni M, Zamani A. Attitudes towards maternal screening for hepatitis B virus infection in Iran. Trop Gastroenterol 2010; 31: 180-183.

24. Ibrahim NKR, Al-Bar H, Al-Fakeeh A, Al Ahmadi J, Qadi $\mathrm{M}, \mathrm{Al}-\mathrm{Bar} \mathrm{A}$, et al. An educational program about premarital screening for unmarried female students in King Abdul-Aziz University, Jeddah. J Infect Public Health 2011; 4: 30-40.

25. Mohammed Abdullah S. Prevalence of hepatitis B and C in donated blood from the jazan region of Saudi Arabia. Malays J Med Sci 2013; 20: 41-46.

26. Weiss MG, Ramakrishna J, Somma D. Health-related stigma: rethinking concepts and interventions. Psychol Health Med 2006;11: 277-287.

27. Dam L, Cheng A, Tran P, Wong SS, Hershow R, Cotler S, et al. Hepatitis B stigma and knowledge among Vietnamese in Ho Chi Minh City and Chicago. Can J Gastroenterol Hepatol 2016; 2016.

28. Rafique I, Saqib MAN, Siddiqui S, Munir MA, Qureshi H, Javed N, et al. Experiences of stigma among hepatitis B and C patients in Rawalpindi and Islamabad, Pakistan. East Mediterr Health J 2014; 20: 796-803.

29. Cotler SJ, Cotler S, Xie H, Luc BJ, Layden TJ, Wong SS. Characterizing hepatitis B stigma in Chinese immigrants. $J$ Viral Hepat 2012; 19: 147-152.

30. Ganczak M. HIV/AIDS education as a supportive tool for premarital HIV screening. J Infect Public Health 2009; 2: 153-154.

31. Al Sulaiman A, Saeedi M, Al Suliman A, Owaidah T. Postmarital follow-up survey on high risk patients subjected to premarital screening program in Saudi Arabia. Prenat Diagn 2010; 30: 478-481.

32. Memish ZA, Saeedi MY. Six-year outcome of the national premarital screening and genetic counseling program for sickle cell disease and B-thalassemia in Saudi Arabia. Ann Saudi Med 2011; 31: 229-235. 